\title{
AFETO ENTRE HUMANOS E ANIMAIS NÃO HUMANOS NO BIOTÉRIO*
}

\author{
Iara Maria de Almeida Souza
}

Universidade Federal da Bahia (UFBA), Salvador - BA, Brasil. E-mail: imas@ufba.br

DOI: $10.17666 / 329407 / 2017$

\section{Introdução}

"Os cães podem ser nossos melhores amigos, mas os camundongos são nossos melhores aliados na luta contra doenças". Essa frase foi dita por C. C. Little, fundador do Laboratório Jackson, um dos principais fornecedores de animais de pesquisa para todo o mundo (Rader, 2004, pp. 21-22). Isso porque, em parte por causa dos esforços do próprio Little e de seu laboratório, os camundongos se converteram em "reagentes biológicos puros a serviço de inúmeras linhas de pesquisa" (Idem, p. 25). Essa concepção acerca dos animais de labora-

* Este trabalho é resultado de apoios concedidos pelo Conselho Nacional de Desenvolvimento Científico e Tecnológico (CNPq), processos 3360002799544376 e 482129/2011-5.

Artigo recebido em 25/10/2015

Aprovado em 12/1/2017 tório parece ser corrente hoje: camundongos são vistos como "instrumentos" ou "vidas instrumentalizadas", equiparáveis a outros componentes do aparato tecnológico-científico. Entretanto, os sinais de protesto e resistência à completa instrumentalização de camundongos, assim como de galinhas e porcos criados em "fábricas de carne", mostram a impossibilidade de uma completa subordinação dos animais a fins alheios aos seus e perturbam a narrativa que os define apenas como vítimas impotentes dos ditames humanos (Haraway, 2008).

Assim como Haraway (2011), em vez de considerá-los vítimas, prefiro tratá-los como trabalhadores atuando em uma pluralidade de contextos de prática científica. Isso implica mostrá-los como criaturas ativas em um ambiente de trabalho, agentes de pleno direito, tanto quando resistem como quando colaboram com os humanos (Despret, 2013). Dizer que eles trabalham (e podem resistir ou colaborar) não equivale, entretanto, a afirmar 
que tenham escolhido livremente participar em pesquisas, nem que inexista assimetria no trabalho; significa retirá-los da posição de passividade na qual sua descrição como seres reduzidos à instrumentalidade - sustentada inclusive por alguns de seus defensores - tende a colocá-los.

Como criaturas vivas eles se envolvem em relaçôes de afeto com outros vivos com os quais compartilham o ambiente. São essas relaçóes que os vinculam aos humanos, especificamente aos técnicos responsáveis pelos cuidados com as criaturas que habitam um biotério, o tema deste artigo. ${ }^{1}$ Obviamente, não pretendo afirmar que pesquisadores sejam imunes a trocas afetivas com animais (e vice-versa) nos contextos de prática científica, como mostram Sá (2010), Sá, Medeiros e Schirmann (2011) e Carvalho (2015). No entanto, os únicos humanos dos quais tratarei aqui são os técnicos do biotério: primeiro, porque é com eles que os camundongos, ratos e hamsters convivem mais amiúde; segundo, porque a contribuição desses trabalhadores é pouco reconhecida nos estudos sobre ciência. A intenção, contudo, não é apenas mostrar que há afetação dos dois lados, dos bichos e dos humanos, mas tentar explorar como estes podem nos dar indicaçóes para pensar sobre ética para além dos aspectos formais das regulamentaçóes.

O contexto de prática do qual tratarei aqui é um biotério de uma instituição pública de pesquisa em biomedicina. É importante lembrar que um biotério não é propriamente um laboratório, mas um local onde os animais que participam de pesquisas nascem, vivem, trabalham e morrem em condiçóes controladas. Em seu interior atuam diversos tipos de controle, sistemas de monitoramento regulam as condiçôes locais de temperatura, umidade etc., técnicos e pesquisadores executam procedimentos padronizados de acordo com as regras de biossegurança e com as exigências das investigaçóes. Por fim, mas náo menos importante, há a legislação que regulamenta a experimentação animal, que é mediada pelo Comitê de Ética no Uso de Animais (Ceua). Como disse, não pretendo me deter aqui nos aspectos éticos do trabalho com animais partindo das regulamentações e da atuação do Ceua, embora reconheça a sua importância, inclusive porque boa parte dos controles mencionados resulta de determinaçōes estabelecidas pela legislação.
Muitas das regulamentaçóes resultam da pressão exercida por ativistas engajados na defesa dos animais. Diversos países, desde o final do século XIX, estabeleceram leis de ordenamento do uso de espécies não humanas em pesquisa. A legislação envolvia um duplo reconhecimento: primeiro, da sua senciência, isto é, sua capacidade de sentir prazer e dor; segundo, de que os experimentos produzem sofrimento. A experimentação com modelos vivos não foi abolida, mas liberada apenas sob certas condiçôes e limites. Era preciso minimizar o sofrimento imposto aos bichos e produzir resultados benéficos. A exigência de um cálculo feito em termos da relação custoxbenefício assegurou a possibilidade de que espécies não humanas se convertessem em ferramentas da ciência (Asdal, 2008). É ainda em grande medida esse princípio que prevalece nas legislaçôes atuais.

As instâncias de regulação estabelecem que tais criaturas, por serem hierarquicamente inferiores, podem ser tratadas como meios para alcançar fins superiores. É justamente a aceitação tão natural desse princípio que Haraway (2011) contesta. Diferente de ativistas que condenam qualquer uso de animais em experimentaçáo, apelando para sua senciência, ela não rejeita por completo sua participaçâo em pesquisas, mas sugere que não basta uma justificativa legítima para garantir uma boa consciência ao matar. Para Haraway, os vivos se envolvem em relaçốs em que a morte de outro vivo está implicada e a instrumentalidade é intrínseca ao ser e ao devir mortal. Portanto, não é possível afirmar incondicionalmente: "Não matarás". Para ela, seria melhor dizer: "Não tornarás matável", ou seja, nós não podemos sentir pleno conforto moral diante da matança dos animais. A experimentaçáo animal pode ser necessária, mas não pode "legitimar" uma relação com o sofrimento de modo regulamentar e insensível. Para ela, cálculos de custo e benefício são necessários, mas insuficientes. Tampouco basta seguir as melhores regras de bem-estar animal, embora isso seja imprescindível. A saída para o problema náo reside em encontrar princípios éticos universais, mas em buscar práticas e políticas imaginativas que rearticulem as relaçôes de mentes e corpos, as criaturas e seu pessoal de laboratório e os aparatos científicos, de modo que suas vidas pos- 
sam se tornar mais interessantes (Haraway, 2011). Um dos lugares em que se podem procurar modos de tornar a vida dos animais mais interessante talvez seja justamente onde eles vivem. Este artigo pretende contribuir nesse sentido. Para isso, primeiro descreverei brevemente o biotério, em seguida tratarei do trabalho dos técnicos e dos bichos e, por fim, das relaçôes de afeto que os vinculam.

\section{O biotério}

O biotério faz parte de uma instituição pública de pesquisa na área biomédica que conta com vários laboratórios voltados para investigação de "doenças negligenciadas", como chagas, esquistossomose, leishmaniose etc. Estas são doenças que, embora atinjam um número significativo de pessoas, usualmente de camadas populares, não interessam à indústria farmacêutica.

No piso inferior de um dos prédios da instituição está o biotério. $\mathrm{Na}$ entrada, à esquerda há uma pequena sala de coordenação. Ela representa praticamente todo o espaço ocupado pela burocracia no biotério, pois a maior parte das atividades acontece nos locais onde vivem os animais. Após a entrada, o espaço se abre para um galpão com uma grande máquina ao centro. Saem dela largos tubos em direção ao teto, semelhantes a chaminés. $\mathrm{O}$ equipamento, que dá um tom fabril ao local, é a máquina de higienização das caixas onde vivem os roedores.

O biotério não é um laboratório. Lá não são forjados artigos, teses, medicamentos. No entanto, o trabalho realizado nele é imprescindível para boa parte dessa produção, pois é ele que provê animais para a experimentação. Em seu interior são reproduzidos camundongos e hamsters, que trabalham para a ciência ao emprestar seus corpos para testes de tratamentos ou para conhecimento de patologias que interessam prioritariamente aos humanos.

Há dois setores principais, o de criação e o de experimentação. No setor de criação são reproduzidos e cuidados camundongos, antes de ingressarem em qualquer experimentação, e as matrizes, como são chamados os casais de camundongos selecionados para reprodução, cujo trabalho é prover novos espécimes para o biotério.
A preocupação extrema com a assepsia em todo o biotério é mais intensa na criação, pois é imprescindível que os bichos permaneçam livres de doença até chegarem à experimentação, para, aí sim, adquirirem apenas a patologia que interessa a determinada pesquisa. $\mathrm{Na}$ criação há normas de biossegurança inquebrantáveis relativas ao controle da circulaçâo de pessoas. Nesse recinto só entram aqueles que atuam no setor e há um protocolo rígido a ser cumprido. O silêncio - que impera (ou deveria imperar) em todo o biotério, pois o barulho perturba e estressa os camundongos - se faz mais presente aí, posto que, quase sempre, o técnico se encontra a sós com seus camundongos e há pouco contato entre os colegas enquanto estão envolvidos com o trabalho.

No momento em que os animais que vivem na criação são recrutados para atuar em uma pesquisa, atravessam o galpão de higienização em direção ao setor de experimentação, que passa a ser sua morada. Nessa ala vivem aqueles que estão engajados em experimentos. Por conta da circulação de pesquisadores - a maioria deles estudantes de graduação ou pós-graduação - é um lugar mais aberto à presença de pessoas alheias à equipe do biotério, e os bichos começam a se acostumar a conviver com uma diversidade maior de humanos. À exceção do trânsito maior de pessoas e da presença nas salas de equipamentos usados em experimentos, como uma esteira ergométrica adaptada, não há grandes diferenças entre a organização das salas nas duas seçôes.

As habitaçôes dos animais ficam em salas com portas parcialmente envidraçadas. Em cada cômodo há caixas transparentes acopladas a uma estrutura metálica semelhante a uma estante. Essa armação é parte do sistema de ventilação que troca o ar dos microisoladores - termo local para as caixas a cada minuto, para que os camundongos não sintam o cheiro de seus excrementos. A temperatura gira em torno de $21^{\circ} \mathrm{C}$. Há também em cada sala um aparelho de fluxo, usado para garantir a permanência do ambiente livre de contaminação quando se faz procedimentos envolvendo manipulação de animais, pois ele lança uma barreira de ar em sua abertura impedindo a troca entre seu interior, onde é feito o procedimento, e o exterior. 
No setor de criação o fluxo só é usado para trocar os bichos de caixa. Na experimentação, o aparelho tem mais serventia, porque, além das trocas, em seu interior são feitas operações mais invasivas, como inoculação de patógenos, coleta de sangue etc. Pesquisadores usualmente vêm ao biotério aos pares ou trios para cumprir com suas tarefas. Alguns deles são novatos acompanhados de seus colegas mais experientes para iniciarem os tratos com as criaturas; outros são companheiros vindos para auxiliar na contenção dos bichos durante a manipulação ou sacrifício. A presença dos pesquisadores, embora seja frequente na experimentação, não é contínua como a dos técnicos. Eles chegam, fazem o seu trabalho e regressam em seguida aos seus laboratórios. Por conta de sua reiterada presença, certas exigências de assepsia são flexibilizadas no âmbito da experimentação, assim como a regra do silêncio é seguida com menos rigidez.

Em todos os ambientes há uma norma controlando a iluminação, pela qual as luzes permanecem acessas entre as sete e as dezenove horas, e apagadas no restante do tempo. É uma tentativa de produzir dia e noite artificialmente, pois o prédio, exceto pela entrada principal, é completamente fechado ao exterior. Mesmo quando alguém precisa eventualmente comparecer à noite ao biotério, a iluminação não é acionada, só é permitido uso de lanterna para não incomodar os animais que precisam dessa sucessão de luz e escuridão. Mas a exigência de não importunar os roedores à noite de modo algum significa zelar pelo seu sono, longe disso. As espécies criadas no biotério são dotadas de hábitos noturnos, portanto, é justamente nas horas de escuridão que eles se encontram mais ativos.

Cada caixa transparente contém entre dois e cinco camundongos. O microisolador é forrado com cama de serragem e possui na parte superior um suporte para o bebedouro e a comida. Tudo isso é trocado semanalmente. No dia da troca os animais são retirados das caixas nas quais estão e levados a outras, idênticas, limpas. Tanto os microisoladores quanto a água, assim como a comida, a serragem e os iglus (falarei sobre eles adiante), passam pelo aparelho de autoclave, que os esteriliza. Todas essas rotinas de troca e limpeza são feitas pelos técnicos.

\section{O trabalho dos técnicos}

O biotério conta com uma equipe de dezesseis funcionários, sete dos quais são mulheres. Eles cuidam da gestão, se responsabilizam pelos cuidados dos animais distribuídos nas salas, pela reprodução de camundongos e hamsters e pela limpeza do local e dos equipamentos. Há um coordenador geral do biotério, os coordenadores das áreas de criação e experimentação, os responsáveis por salas, os encarregados da reprodução, do corredor e da limpeza. Além da diferenciação de tarefas, há outra categorização que atravessa o biotério, com os funcionários dividindo-se em concursados (entre os quais há doutores, graduados e técnicos de nível médio) e terceirizados (todos com nível médio, apenas um deles faz curso superior). Os primeiros tendem a ser mais qualificados, podem ocupar cargos de gestão, têm remuneração maior e gozam dos direitos trabalhistas reservados aos funcionários públicos. Os últimos são contratados por uma empresa prestadora de serviços, usualmente possuem menos anos de estudo, ganham menos e estão mais sujeitos a demissóes, embora seja importante ressaltar que aqueles que lidam diretamente com animais tendem a permanecer estáveis quase todos estão lá há mais de cinco anos, a despeito de ter havido mudança da empresa prestadora de serviços à instituição nesse período.

Todos os trabalhadores da higienização são terceirizados, bem como a maioria dos técnicos encarregados das salas. No passado, estes últimos eram recrutados em uma escola técnica rural próxima a Salvador. Atualmente a entrada deles se dá pela via da higienização. Depois de avaliado o comportamento, a assiduidade, o zelo e habilidade para lidar com os roedores quando cobre faltas eventuais ou férias de colegas, é possível que um funcionário da higienização seja chamado para ocupar a função de técnico quando houver vaga. Deixar a posição de encarregado da limpeza para cuidador dos bichos representa uma ascensão na carreira funcional, envolve a aquisição de uma expertise - porque ele tem de passar por um aprendizado mais sistematizado do trabalho - que pode garantir a permanência por longo tempo no local, além de oferecer ao trabalhador a chance de um ofício considerado muito prazeroso por eles. 
$\mathrm{Na}$ divisão de trabalho do biotério, os coordenadores de setor - veterinários ou biólogos - cuidam das tarefas burocráticas: fazem o levantamento e a compra de material, participam de comissóes e comitês da instituição, lidam com o serviço de manutenção e com as demandas dos pesquisadores, escrevem relatórios e preenchem formulários. Ao assumir postos mais altos na hierarquia, dizem eles, acabam se afastando daquilo que há de mais agradável no seu trabalho, que é o contato com os animais (a despeito das tarefas penosas que isso envolve). Ficar "lá dentro", na calma do ambiente em que estão os bichos é bem melhor do que estar "do lado de fora", lidando com as demandas diversas da instituição. A coordenadora da experimentação lamenta passar todo o dia a cuidar do defeito na porta, do material não entregue, a escrever e-mails e participar de reunióes. Resta a ela, segundo diz, pouco tempo para o que lhe apraz, isto é, observar e cuidar dos camundongos e ratos. Isso quem faz são os técnicos responsáveis pelas salas.

À exceção dos coordenadores de setor e dos trabalhadores da higienização, que transitam entre vários espaços, cada técnico é encarregado de uma sala. Ao chegar ao biotério, antes de entrar no local onde vai passar as horas com suas criaturas, o técnico deixa as roupas com as quais chegou em um armário, toma banho lavando o cabelo e veste seus trajes profissionais: macacão, gorro, luvas, máscaras e sapatilhas. No caso dos que trabalham na criação, a cada vez que saem - para ir ao banheiro ou se alimentar -, antes de retornar a sua sala, é preciso repetir todo o ritual: se despir, tomar banho e se paramentar. Por isso, a equipe da criação negociou com o coordenador a antecipação do horário do almoço, assim o lanche da manhá foi suprimido e, por conseguinte, um banho a menos requerido.

O técnico responsável por uma sala deve estar atento a tudo que afeta o bem-estar dos animais. Por isso, logo cedo, assim que entra no recinto, sua primeira missão é observar o interior das caixas e ver como estão os bichos, verificar se algum deles está morto ou ferido, se estão com os pelos eriçados ou olhar mortiço (pode ser sinal de doença), se há algum andando em círculos continuamente, mordendo as grades, retirando compulsivamente pelos seus ou dos companheiros (sinais de estresse), se há água e alimento suficientes nas caixas. Ao observar qualquer sinal de problema ou alteraçáo é preciso procurar o coordenador do setor e comunicar a ele a ocorrência. É necessário também fazer o registro por escrito. Há ainda um formulário a ser preenchido com os dados sobre as condiçôes locais, como a temperatura e o funcionamento do sistema de troca de ar. As atividades realizadas também são registradas a cada turno. Este é o quinhão burocrático do trabalho e também a parte que envolve diretamente a prestaçáo de contas sobre as atividades. A arquitetura projetada para dar uma grande visibilidade ao local de trabalho do técnico poderia sugerir que se trata de um dispositivo de vigilância sobre os trabalhadores, mas parece não ser assim para eles. Portas transparentes não anulam o senso de que ali eles estão a sós com os animais e alguns não se furtam a fazer coisas que, se não são proibidas, tampouco constam dos protocolos, como eventualmente conversar ou cantar para os bichos. O silêncio deve ser cultivado, mas, para eles, o som de uma voz conhecida, de alguém com quem eles convivem diariamente, não tem qualquer efeito estressor, diferente de outros ruídos.

Em todos os setores há uma rotina nas atividades das salas, alguns dias são destinados à limpeza e outros às trocas de caixas. Os técnicos limpam as estantes (os funcionários de higienização purificam o piso e as paredes), organizam todo o ambiente, se encarregam de nutrir, limpar, identificar e cuidar dos animais. Ao contrário do que é demandado em muitas ocupações, aqui não há exigência de rapidez no desempenho das tarefas. Eles dizem que durante seu treinamento e mesmo depois há uma insistência reiterada de que tudo seja feito com calma e no ritmo apropriado, as coisas não devem ser movidas de modo ruidoso ou desleixado, os bichos não podem ser tocados bruscamente. A delicadeza é mais importante que a celeridade. E é preciso cultivar sobremaneira a atenção.

A sexagem, identificação do sexo dos recém-nascidos, é um dos trabalhos dos técnicos da criação que exige um tanto mais de refinamento da atenção. Não é exatamente simples saber, no momento do desmame, qual deles é macho ou fêmea. É preciso adquirir a habilidade de tocá-los e vê-los de modo apropriado a fim de reconhecer seu sexo. 
No momento em que é feita a sexagem, também se realiza a seleção daqueles que serão convertidos em novas matrizes. Os escolhidos são os espécimes que representam melhor as características da linhagem em termos de tamanho e pelagem. É o olhar treinado do técnico que classifica, entre todos, aqueles que servirão como exemplares mais bem-acabados da linhagem. Bartira, ${ }^{2}$ que se declara casamenteira e tem gosto em formar pares, diz que além da aparência, há algo mais envolvido nesse processo: uma capacidade adquirida com o tempo de reconhecer quais animais possuem afinidade para viver juntos como casal.

Tanto nas horas em que estão mais ativamente envolvidos em alguma tarefa quanto em momentos de mais calma, uma das missóes fundamentais dos técnicos é prestar atenção aos animais: vê-los, ouvi-los e tocá-los nos dias de troca. Seu zelo tem essa qualidade sensorial, exige um engajamento de seus sentidos no trabalho. Também é preciso, quando se permanece "lá dentro", entrar na sintonia e no ritmo apropriado aos bichos e se deixar levar pela calma. Para eles, no convívio duradouro com essas criaturas são estabelecidas relaçóes que envolvem, segundo dizem, reconhecimento mútuo. E as horas que passam sem outros humanos, gozando da companhia de "seus" animais representam momentos de grande prazer no trabalho.

Esses personagens e suas práticas são bem pouco mencionados nos estudos de ciência. A maior parte deles não é de pesquisadores, mas seu trabalho contribui para que a ciência seja feita. É tentador dizer que eles são, como os próprios bichos, trabalhadores imprescindíveis para a prática da ciência, mas presenças muito discretas nos relatos sobre a vida nos laboratórios. Eles são, assim como os roedores, frequentemente tratados como meras ferramentas a serviço da atividade de pesquisa.

\section{O trabalho dos animais}

Os camundongos que trabalham no biotério nascem no setor de criação. Os hamsters, criados em número reduzido, vivem em uma sala em outro prédio - uma espécie de extensão do biotério funcionando nos mesmos moldes, igualmente sub- dividida em criação e experimentação. Já os ratos, pouco presentes, vêm de outras instituiçóes. Como no espaço principal do biotério são reproduzidos apenas camundongos, tratarei exclusivamente deles, inicialmente.

A uma parte dos camundongos é destinada a tarefa de procriar continuamente para manter a população de modelos experimentais do biotério no nível requerido pelas pesquisas. É importante salientar, entretanto, que essa população regrediu bastante nos últimos anos, com o aumento do rigor do Ceua e do próprio biotério para a liberação de animais para os projetos. Ainda assim há alguns milhares deles na instituição.

O trabalho de reprodução de novos espécimes faz parte das atribuições dos pares de camundongos chamados de matrizes. A cada prenhez nascem cerca de oito filhotes. Logo depois do nascimento de uma ninhada, o casal copula e a fêmea inicia uma nova gestação que dura o mesmo tempo de amamentação dos recém-nascidos. Com 21 dias de vida, os filhotes são retirados do convívio com os pais, mas o casal não fica sozinho, uma vez que logo chega a nova ninhada e o trabalho de amamentação e ensino dos filhotes - de como se limpar e comer ração, por exemplo - recomeça. A vida em comum da parelha perdura enquanto ela mantiver o mesmo nível de produtividade. Depois de um tempo, quando o número de filhotes a cada ninhada decresce, o trabalho deles é considerado concluído e seu destino será o descarte, mesmo que eles estejam saudáveis e pudessem viver por mais tempo.

No início de sua vida, cada camundongo compartilha a caixa com os pais e os irmãos da mesma ninhada. Quando nascem os filhotes, as mães adotam uma atitude de defesa da prole, e os recém-nascidos inicialmente apenas dormem e mamam, tornando-se aos poucos mais ativos e curiosos. Enquanto são amamentados, eles começam a experimentar pequenas porçóes de ração oferecidas pelos pais ou pedacinhos de comida que caem na caixa. Também nessa fase começam a interagir com os companheiros e a se acostumar à presença de humanos.

Aqueles não escolhidos como reprodutores serão destinados à pesquisa e depois do desmame viverão na mesma caixa com irmãos do mesmo sexo. O principal e mais óbvio motivo para esse arranjo 
é a necessidade de controlar a procriaçáo, pois, ainda que a produção de novos animais seja um dos trabalhos desempenhados pelos camundongos, isso deve ser feito sob o controle dos técnicos.

Os destinados à experimentação não terão contato íntimo com outros além daqueles com quem compartilham a caixa, jamais viverão fora de um microisolador, náo pisarão com suas patinhas no chão (a menos que consigam fugir), nem terão de se esforçar para obter alimento e água. O que é exigido deles é colaboração nos experimentos. Mas há alguns modos de se negar a isso. Um deles é a recusa à convivência mais ou menos pacífica com os companheiros. Nesse ambiente restrito, dizem os técnicos, as fêmeas vivem mais harmoniosamente, sem muitas brigas e estresse e os machos são mais dados a confrontos físicos. Com efeito, alguma violência é tolerada nas caixas masculinas. Mas há alguns cujo anseio por lutar ultrapassa o limite aceitável, deixando seus parceiros demasiado feridos ou mortos. Nesse caso, é preciso interferir e identificar o "brigão". Como reconhecê-lo se todos são idênticos? Ele é sempre o que está menos machucado. Tendo se revelado incapaz de viver com outros em algum tipo de acordo, ele é retirado do convívio dos irmãos e destinado ao "descarte", pois seria impossível integrá-lo a outro grupo ou deixá-lo na solidão. No dia da eutanásia o animal é levado pelo técnico a uma câmara de gás. Fica só. $\mathrm{O}$ dispositivo que libera $\mathrm{CO}_{2}$ é acionado levemente, ele sente uma sensação de tontura e desmaio, só então o nível de $\mathrm{CO}_{2}$ é elevado, e em seguida se dá sua morte.

Os que não são "brigões" podem sobreviver por mais tempo, mas raramente ultrapassam um ano. O tempo de permanência deles na criação, antes da ida para a experimentação, é incerto. Não raro eles aguardam por três meses até que atinjam o peso ou a maturidade desejada pelos pesquisadores. Nessa fase de espera, a vida deles consiste basicamente em dormir a maior parte do dia, acordando eventualmente para beber água, comer ou brincar com os companheiros. À noite, longe dos olhares humanos, eles se dedicam às brincadeiras ou brigas.

Semanalmente o técnico responsável pela sala tira a caixa da armação e leva para o aparelho de fluxo, pega cada um dos camundongos pelas costas de um jeito que ele sabe que os animais gostam, pois lembra o modo como suas mães os carregavam - e os coloca em outra caixa perfeitamente limpa. Talvez nesse momento os camundongos sintam seus pelos acariciados e ouçam vozes se dirigindo a eles. Ao serem postos de volta na caixa, de início se movimentam inquietos, curiosos, dando voltas e cheirando tudo, mas logo ficam à vontade na morada. Depois a caixa retorna para a estante, e eles, para sua rotina de brincadeiras, brigas, sono, comida e água.

O tempo de espera na criação é mais do que uma fase de não trabalho para os animais, é efetivamente um período de socialização que os prepara para a convivência e a colaboração com os humanos que logo entrarão em suas vidas trazendo agulhas, medicamentos, dispositivo de contenção e exigindo deles outros comportamentos. Sem a aquisição de confiança nos humanos que se dá nessa fase, o trabalho posterior seria impossível. Por exemplo, Nina, uma pesquisadora, conta que certa vez precisou de ratos de rua para obter capilária, um tipo de verme, para sua pesquisa. Ela os pegava com uma armadilha e os levava para o laboratório. Acontece que eles eram intratáveis, mesmo usando luvas de couro grossas, ela e o técnico não conseguiam tocar neles tal era sua ferocidade. Para que os ratos pudessem ser manipulados e seus fígados retirados improvisaram um artifício para sedá-los (a gaiola foi colocada em um saco grande, com chumaços de algodão com éter) e só então fazer o sacrifício. Ela diz: "Os camundongos de laboratório são supertranquilos. Você pega o animal, bota aqui em cima de você e ele não vai lhe fazer nada. [...] Esses de rua não permitem porque eles nunca tiveram esse contato". A tranquilidade dos camundongos do laboratório resulta da experiência prévia no ambiente do biotério com cuidadores, que faz com que o contato com outros não lhes suscite pavor e uma resposta feroz. Ainda assim, não há garantia plena de que aceitarão de bom grado as manipulaçóes às quais são submetidos. Vários humanos já testemunharam sua recusa sob a forma de mordidas e agitação.

Quando sáo recrutados para a pesquisa, os camundongos são postos em uma caixa grande e transportados para a experimentação em um caminho sem volta. Chegando lá são acomodados em caixas idênticas às que habitavam antes, contendo uma etiqueta que os identifica, com informaçóes 
sobre sexo, idade, peso e a pesquisa da qual participam. Também ali são cuidados por um técnico com o qual convivem até o fim da vida. Eles ouvem sua voz, são tocados e vistos pelo responsável pela sala. Mas novos personagens - os cientistas - entram em seu campo de experiência, com os quais interagem com maior ou menor intensidade a depender da pesquisa. São eles que introduzem o animal mais diretamente no trabalho experimental, boa parte das vezes isso resultará em seu adoecimento. Por vezes, camundongos ingressam na pesquisa participando do dispositivo para a proliferação e reativação de agentes patológicos, como cepas de Tripanossoma cruzi, mantidas em cultura de células, cuja virulência se abranda depois de muito tempo sem enfrentar os desafios de sobreviver e se multiplicar em um organismo. Nesse caso, indivíduos mais novos, recém-desmamados, são indicados para o trabalho, pois seu sistema imunológico pouco robusto malogra na defesa contra a infecção.

$\mathrm{Na}$ maioria dos casos o trabalho dos cientistas envolve o adoecimento de seus modelos experimentais, às vezes de dezenas deles. A conversão de um animal saudável em doente, pela inoculação de um agente patológico, se dá de diversos modos, por exemplo, por meio de injeção, contato com a pele ou ingestão de substâncias. Quem faz isso são alguns humanos que se inserem na vida dos roedores, tiram sua caixa da estante, colocam-na em uma bancada, retiram-nos do microisolador e, com uma mão enluvada - assim como a dos técnicos -, importunam seu sono ou brincadeira, imobilizam-nos e manipulam seu corpo. O bicho tenta se mexer, morder ou escapar desses novos humanos. Depois dessa primeira manipulação pode sobrevir um senso de debilidade, febre, pelos eriçados e sem brilho, a cessação dos movimentos até a morte chegar. Há cepas de Tripanossoma cruzi que podem matar um camundongo em poucos dias. Mas há agentes patogênicos menos agressivos ou tratamentos mais eficazes, que permitem uma vida mais longa, se a pesquisa assim determinar, pois é sempre ela que marca o limite. Quando há teste de medicamentos, os pesquisadores não apenas inoculam agentes patológicos, mas voltam a interagir com os seus modelos experimentais para a administração de drogas e avaliação de progresso da doença e do tratamento.
Enquanto estão vivos os animais são visitados pelos pesquisadores com assiduidade, às vezes diariamente. Eles vêm durante o dia, por vezes apenas para ver como estão seus camundongos, ratos ou hamsters. Mas, reiteradamente, os bichos são perturbados pelos pesquisadores. Não raro os passos descritos acima se repetem, da estante para a bancada ou fluxo e daí para as mãos do pesquisador que o manipula. Por exemplo, pode ser que uma mão segure a cabeça do camundongo pela parte de trás do pescoço, impedindo-o de reagir à intromissão com uma mordida - o que ele pode tentar e eventualmente conseguir - enquanto outra mão enfie uma agulha no seu abdômen injetando um líquido. $\mathrm{Ou}$ tras vezes, o animal é posto em um dispositivo de contenção que prende seu corpo e impede sua fuga e mordidas. Quando isso acontece ele pode sentir uma picada na cauda, seguida de um calor intenso. No início isso causa temor e ansiedade, mas, depois de muitas repetições, ele aprende que tais incômodos são temporários, que logo será colocado de volta em sua caixa e, entáo, tende a cooperar um pouco mais com aqueles humanos, esforçando-se menos para morder ou se soltar. Às vezes algumas negociaçôes são necessárias para garantir a colaboração. Diana, uma mestranda, conta que ao iniciar uma pesquisa envolvendo a administração de uma droga com gosto amargo enfrentou objeçóes dos animais ao medicamento. A droga, diluída em um líquido, era servida em uma pequena seringa, cujo conteúdo deveria ser sorvido por eles. Primeiro ela diluiu o remédio em água e a rejeição foi absoluta (eles cuspiam todo o medicamento), depois tentou usar soro e a resposta não foi melhor. Por fim, dissolveu o remédio em água com açúcar, e só então o sucesso foi alcançado. Segundo ela, a aprovação foi tal que os camundongos agarravam a seringa com a patinha com um gesto semelhante ao de bebês segurando a mamadeira.

Nem sempre é preciso negociar tanto para a administração de remédios. Alguns dispositivos contribuem para tornar essa tarefa menos penosa para os pesquisadores. Por exemplo, é comum o uso de uma espécie de agulha longa com a ponta esférica acoplada à seringa para introduzir o medicamento pelo esôfago do animal e minimizar o risco de perda da droga pela cuspida ou por con- 
ta da agitação do bicho. Tal método é mais eficaz porque garante a "entrega" da substância na dose apropriada. Ainda assim, o dispositivo não elimina por completo a necessidade de negociar a colaboração do camundongo. A concessão ao paladar está certamente fora de questão, mas é preciso que ele se habitue à agulha introduzida em sua garganta. Os pesquisadores dizem que no início é difícil contê-lo, é preciso cuidado e delicadeza, mas também firmeza no modo de segurá-lo. Com o tempo a tarefa se torna menos árdua. Circula uma anedota nos laboratórios: ao final do experimento os bichos estão tão habituados que fazem eles mesmos a entubação. Há uma série de outros procedimentos que demandam deles maior ou menor disposição de cooperar. Em alguns casos de leishmaniose, para avaliar a progressáo da doença e do tratamento é preciso medir a pata do animal com uma pinça, e ele precisa deixar que isso aconteça. Às vezes o protocolo exige que ele aprenda a correr em uma esteira ergométrica ou não se incomodar enquanto alguém passa pomada em seu câncer de pele etc. A depender do protocolo de pesquisa as demandas que recaem sobre os bichos podem ser bastante variadas e a exigência de cooperação pode ser maior ou menor, mas em nenhuma circunstância ele pode ser tratado como parte passiva da experimentação.

Com o tempo, mesmo que a doença náo tenha levado o camundongo à morte e que o tratamento seja bem-sucedido, chega o momento do sacrifício. A morte vem sem dor em virtude do anestésico administrado. Com efeito, na realização da pesquisa, seguindo as diretrizes éticas, alguns recursos devem ser usados para minimizar o sofrimento dos animais. Em especial na hora da morte, há uma grande preocupação com a analgesia. Só quando há sinais incontestáveis de que a sedação está completa o bicho é morto, provavelmente por meio do método de exsanguinação. $O$ pesquisador colhe seu sangue e partes de seu corpo são fragmentadas, congeladas e transformadas em material de análise, registradas em fotos e imagens a fim de comprovar, em um artigo ou tese, aquilo que o pesquisador afirmar.

Durante toda a vida, a criatura pode ser submetida a muitos procedimentos, como os mencionados, e mesmo quando sua frequência é diária não ocupam todo o seu tempo. São poupados de lutar pelo próprio sustento, mas não encontram fácil salvação do tédio e do estresse. Para sanar parcialmente esses males e trazer um tanto de diversão ao ambiente, um elemento lúdico foi incorporado a cada habitação. Trata-se de um pequeno iglu com várias entradas, feito de um material transparente vermelho, quando visto pelos humanos, mas que os animais enxergam como preto. Esses iglus são usados com fins diversos: brincadeira, sexo, sono e ainda como banheiro. Papel toalha também tem uma função a desempenhar na busca por diversão. Quando posto nas caixas, os animais se entregam de imediato à folia de rasgá-lo. Ainda assim, essas iniciativas de "enriquecimento ambiental" não logram a abolição completa do tédio e do estresse. Seus sinais são notados em vários aspectos comportamentais e na aparência: andar de modo inquieto, rodar continuamente, brigar em excesso, perder pelos. Tânia, técnica da criação, diz: "O DBA2 é lindinho, tem o pelo bem macio, bonitinho. Mas quando eles estão estressados, aí começam a sair pelos. Às vezes, eles ficam sem pelo nenhum, é... Imagina o bicho se estressando, sem ter conta pra pagar...”.

Tânia compara a vida dos animais à sua ao dizer que eles não têm conta a pagar e por isso náo deveriam se estressar, mas eles de fato passam por situaçóes tensas. Algumas são transitórias, como barulhos, manipulaçóes ou o desmame, mudança na ração ou no detergente; outras são permanentes. Como afirma o coordenador Xavier, o próprio fato de viver em um ambiente confinado é em si uma fonte de estresse (por isso a necessidade do "enriquecimento ambiental”). As rotinas são rígidas, eles convivem apenas com seus irmãos da mesma caixa, têm pouco contato com outros vivos, apenas com técnicos e pesquisadores, que se apresentam para eles com paramentos idênticos.

Se a vestimenta com que os humanos se apresentam talvez não interesse tanto a eles, certamente são mais marcantes a voz, o toque ou o odor singular daqueles com quem convivem ao longo do dia, porque a visão não é um sentido tão importante quanto o olfato e a audição, e por isso cheiros fortes e ruídos podem ser tão estressantes.

Para muitos dos trabalhadores humanos o momento preferido do trabalho é o da troca de caixa, 
quando eles entram em contato com os animais sem barreira. Alguns aproveitam para acariciar seu pelo ou para deixar a mão pousada na caixa e ver o que fazem. Há também quem se admire com seus esforços para saltar uma grande altura e alcançar o desconhecido. Em geral essa é para os técnicos uma ocasião de intensificação do afeto e da troca corporal. A capacidade para a afetação é algo que define tanto os corpos de humanos quanto de animais.

\section{Afetos}

Meu objetivo é justamente chamar a atenção para os afetos que permeiam as trocas entre humanos e animais. Afeto entendido aqui no sentido dado por Despret (2004) de afetação, ou seja, de ser afetado e movido por outro. Afeto, por conseguinte, não corresponde exatamente a sentimentos ou emoçóes específicas, individualizadas, que têm uma origem na psique de um sujeito. Em vez de remeter para a interioridade como origem, é importante ter em conta que afeto é relacional, vincula os agentes e é sempre algo de natureza indeterminada, que circula entre o corpo, o mundo e a consciência (Idem). A busca por causas primeiras quando tratamos de afetos nesses termos, por conseguinte, é uma tarefa vã: não há como determinar quem influencia quem, onde tudo começa e também não há como deixar de lado o ambiente que permite a expressão de certos comportamentos e afetos e não de outros.

Certamente não sou a primeira a observar a existência de afetos e intersubjetividade entre humanos e animais na prática científica (Despret, 2008; Sá, 2010; Candea, 2010). Ocorre que usualmente os humanos dos quais se fala nesses estudos são pesquisadores, quase sempre etologistas trabalhando em campo em um ambiente muito distinto do biotério. Quando a literatura se volta para as entidades vivas que levam suas existências em biotérios e laboratórios, convertidas em recurso para a pesquisa, a menção aos vínculos afetivos que as unem aos humanos é algo escassa. A despeito das exceçóes (Sá et al., 2011; Holmberg, 2011; Carvalho, 2015), o interesse maior gira mais em torno do tipo de conhecimento que se obtém com o uso de modelos animais do que propriamente do modo como eles respondem à situa- ção e a suas relaçóes com os humanos (Davies 2010; Birke, 2012). Lynch, em seu artigo seminal, se interessa principalmente em mostrar como o animal vivo, "natural", é ritualmente transformado em animal "analítico" no laboratório. Ele não deixa de reconhecer que o trabalho com ratos requer habilidade e empatia para lidar com eles (Lynch, 1988, p. 282). Contudo, não explora essa questão mais detalhadamente. Também Birke (2012) considera a importância das relaçóes empáticas envolvendo técnicos e modelos experimentais, mas não extrai muitas conclusóes de tal fato, enfatizando as implicaçóes científicas dessa forma de experimentação para o modo como os corpos humanos são concebidos.

Ao fazer entrevistas com técnicos do biotério, observei, entretanto, que a existência de certo tipo de afeto ou afinidade envolvendo humano e animal, bem como a afirmação da necessidade de sintonização com os bichos para compreender o que é significativo para eles, não é um aspecto incidental ou secundário das práticas que têm lugar no recinto. Ao contrário, o desenvolvimento de uma sensibilidade para com os animais, a capacidade de se deixar afetar por eles, que cresce a partir da convivência, é considerada um requisito para o cuidado realizado pelos técnicos. Também é sempre mencionada a necessidade de criar e preservar uma atmosfera de serenidade no local de trabalho.

O que Xavier [o coordenador] mais preza é tranquilidade e calma. Ele diz: "Façam seus trabalhos com calma, sem pressa, pra não maltratar eles, né?” A gente tem o maior cuidado com os procedimentos, tudo com calma, sem barulho (Damasceno, técnico da criação). Ele [animal] reconhece a pessoa que trabalha calmamente... Porque no biotério náo deve ter aquela pessoa agitada que faz as coisas... Você tem que ser o mais calmo possível, porque se você fizer um barulho - paf - todos os animais da sala vão se assustar (Zacarias, técnico do controle de qualidade).

Eu ficava em uma sala que era eu e eles, entấo, meu dia era aquilo. Eu chegava, entrava na criação, ficava ali só eu com os animais, cuidando deles em paz (Lena, técnica do controle de qualidade). 
A exigência de silêncio ou do tom manso na fala, o ritmo lento dos movimentos, o manejo cuidadoso das coisas, a delicadeza no toque, tudo isso compóe o ambiente em que se dá o encontro entre humanos e bichos e participa do arco dos afetos que tem lugar ali. Isso significa que os afetos não só não se encontram exclusivamente na interioridade dos sujeitos, mas tampouco são apenas diádicos: humanos, animais e ambiente se fazem em consonância. Ademais, a necessidade de fazer as tarefas em silêncio e com calma, sem pressa para não estressar os roedores, pode produzir nos humanos uma sensação de serenidade, que se estende para além dos limites do biotério, como no caso de Bartira (técnica da criação): "Eu era muito agitada, nervosa, não levava desaforo pra casa, mas melhorei bastante, tô aprendendo a ter paciência, entendeu? Tipo, você trabalha com animal, você tem que ter muita paciência, então, isso aí tô levando pra vida. A convivência com as pessoas melhorou".

Assim como é possível ser afetado pelo ambiente de tal modo que uma disposição aí adquirida acabe por ressoar em outros âmbitos, também acontece de alguém encontrar no ritmo do biotério algo que convém para si. Tatiana, que anteriormente trabalhou no comércio e experimentou certa disjunção com aquele ambiente, agora se sente mais em consonância com a atmosfera do biotério. "Eu não tenho dom pra trabalhar com uma pessoa apertando minha mente. E aqui é um trabalho tranquilo, sem tumulto e agitação... Eu gosto muito disso. É mais fácil lidar com os animais porque se você transmite tranquilidade, você tem aquilo de volta, eles ficam tranquilos..." (Tatiana, técnica da experimentação).

Ao mesmo tempo que Tatiana afirma que aprecia a quietude do local, diz também que sua tranquilidade acaba por acalmar os animais. Há uma espécie de contágio da disposição afetiva, sem que se possa determinar precisamente onde começa e acaba. A existência de transmissão de disposição de um a outro dos vivos que se encontram no biotério também é reconhecida por outros técnicos:

Tocar o animal não pode ser de qualquer forma. [...] e aquela questão também, se você estiver estressado, ele também fica (Tânia, técnica da criação).
Eu acho que eles sentem também o seguinte, se você tá muito agitado, eles ficam agitados também, você acredita? Você tá triste, eu acho que eles sentem sua tristeza... (Deraldo, técnico da criação).

Quando a gente pega com cuidado, você encosta na caixa e eles vêm te olhar, não sentem aquele medo. [...] Também, se a pessoa encostar no animal com medo, o animal sente logo (Damasceno, técnico da experimentação).

Outro técnico, Quirino, quando sacrifica hamsters procura não demonstrar pesar em sua presença, pois, segundo diz, eles sentem e podem sofrer com isso. Ao dizer que os bichos são capazes de perceber a disposição de seu cuidador e reagir a isso, Quirino fala da existência de sintonia entre eles. Outros, também afirmam que eles são capazes de sentir e responder ao estresse ou à tristeza de quem cuida deles.

Não apenas os animais se contagiam - são afetados - por disposiçóes daqueles com quem interagem, como dizem seus cuidadores, mas também, depois de certo tempo de convivência, eles são capazes de reconhecê-los. "Com certeza eles conhecem quem cuida deles, eu tenho um colega que falava muito alto e já teve vez de eu estar trocando a caixa, ele entrou conversando, o bicho ficou todo estressado, agitado porque aquela voz não é conhecida dele, entendeu?" (Tânia, técnica da criação).

$\mathrm{O}$ reconhecimento nem sempre significa o estabelecimento de uma relação harmoniosa. É possível falar da existência de afinidades desconcertantes, atravessadas por "linhas de diferença" (Connolly, 2005).

Um rapaz que trabalhava aí tinha um jeito rústico, pegava o bicho de qualquer jeito, os bichos fechavam o olhinho... (Damasceno, técnico da experimentação).

Tinha uma pessoa que não podia mexer num rato. Se ele fosse trocar o animal, o jeito que ele pegava, o bicho saía pra morder ele a três por dois, entendeu? Ele tomou mordida de rato, e rato é um animal superpassivo, é um amigo. [...] Damasceno, por exemplo, não pega pelo rabo, pega pelo corpo, o animal sente e gosta disso. 
Ele é outro, fica mansinho, conhece a pessoa (Silvana, coordenadora da experimentação).

O momento de tocar o animal parece ser mesmo uma das situaçóes em que há uma intensificação dos afetos, tanto aqueles malfazejos - como no exemplo anterior - quanto aqueles mais afáveis e prazerosos.

A parte da troca é que eu gosto mais, porque, sabe... quando é você e os bichos, gosto de tudo, porque só tem eu e eles (Tânia, técnica da criação).

Às vezes, tô assim trocando, aí eu acho interessante os animais, eu digo: "Oh, rapaz, que negocinho bonitinho, esse aqui tá lindo”. Às vezes fico coçando a cabeça dele. [...] Os animais gostam de carinho. Quem é que não gosta de carinho? (Deraldo, técnico da criação).

O circuito de troca de afeto entre Deraldo, um técnico terceirizado, e os camundongos é muito distinto daquele mostrado no primeiro exemplo. $\mathrm{O}$ desconforto do rato ao ser tocado de modo bruto se expressa no modo de fechar os olhos e na resposta agressiva. Deraldo, por sua vez, se interessa pela beleza dos animais e os acaricia. O toque é diferente, mas ambos fizeram o mesmo treinamento. Qual é então o treinamento e quais são os critérios para alguém ser considerado bom trabalhador no biotério?

Qualquer um que é admitido para o trabalho no biotério faz curso de biossegurança, porque é fundamental conhecer as regras para lidar com material contaminante. Também é preciso seguir o curso de manipulação de animais, com vídeos e palestras. Isso, claramente, é insuficiente para que se adquira a habilidade requerida no trabalho. As rotinas, protocolos e os modos de tocar o animal são aprendidos na prática com aqueles que estão lá há mais tempo. É acompanhando alguém no trabalho, observando o que o outro faz, ouvindo suas explicaçóes e sendo aos poucos testado nas tarefas, inclusive no modo de tocar o bicho, que a pessoa vai se tornando apta para a função. Há também a aquisição de certo tipo de disposição para o silêncio, adoção de um ritmo calmo etc. Ou seja, é pre- ciso uma familiarização com o ambiente e com as criaturas vivas (também estes, como vimos, aprendem a responder aos humanos e a cooperar com ele). É Xavier, o coordenador, quem dá o aval para a pessoa prosseguir sozinha no trabalho: "Aí treina, treina direitinho, quando Xavier vê que você realmente pode ficar, aí ele te entrega a sala. É toda sua" (Tânia, técnica da criação).

Na seleção para o emprego, Xavier (e os próprios técnicos, também) considera importante a existência de experiências prévias de contato com animais. Já ter uma sensibilidade de algum modo desenvolvida favorece o aprendizado, além de diminuir o medo que por vezes toma os iniciantes no ofício.

Desde pequeno eu sempre tive contato com animais. Meu pai era técnico do Ibama, aí os animais que não podiam retornar ele sempre trazia pra mim. Até hoje tenho muitos animais em casa. [...] Eu acredito o contato com animais desde pequeno é importante... Uma pessoa sem intimidade com o animal, para chegar e trabalhar diretamente com eles fica meio sem jeito, até pegar o costume demora... (Damasceno, técnico da experimentação).

Aqui eu tive hamster. Lá em minha cidade tenho uma cachorrinha. A vida toda eu tive animal, nem consigo me imaginar sem um bichinho. [...] Eu acho que isso tem diferença para o trabalho, porque quando você tem o hábito de conviver com o animal, você tem um olhar diferente pra ele, tem mais cuidado, aquela coisa mais humanizada. E quando você não tem [...] olha pra eles simplesmente como um objeto de trabalho. Eu acho que o animal sente a diferença do toque (Tatiana, técnica da experimentação).

Entre todos os técnicos, Deraldo parece ser o mais afeito aos bichos e o que tem na companhia deles, dentro ou fora do biotério, mais prazer. Ele é um homem de meia-idade, sorridente e afável, que sempre teve um grande amor pelos animais e os criava para seu deleite. Diz ele: "Desde pequeno, criei lá em casa cachorro, preá, passarinho, camaleão, mico, até um cacheiro, o pessoal chama de ouriço. Minha casa era meio que selva...”. Tanto 
na fala de Deraldo quanto na de Tatiana fica claro que, a despeito do biotério ser um lugar em que os camundongos, ratos e hamsters são instrumentalizados, para os trabalhadores a relação nunca pode ser só instrumental: os bichos não podem ser vistos como objetos de trabalho. Esse modo mais sensível de lidar com o animal, em que se observa o modo como ele responde ao cuidado, é também um critério usado por Silvana, coordenadora da experimentação, para selecionar aquelas pessoas que, tendo ingressado no biotério via higienização, serão promovidas para o trabalho de técnico. Ela chama a isso de amor (assim como Deraldo, Quirino e Damasceno): "Eu observo, presto muita atenção e dou valor quando percebo que a pessoa tem um olhar diferenciado pro animal, entendeu? Não vê o animal como uma coisa qualquer. Um olhar diferenciado de amor mesmo, entendeu?"

Silvana, embora pareça severa, mostra-se branda quando insiste em que é imprescindível amar os animais para trabalhar com eles. Saber lidar com os bichos de modo carinhoso e sensível é importante, até mesmo porque a maioria dos trabalhadores, ao entrar na instituição, não possui treinamento para a tarefa.

Deraldo, por exemplo, ao ser contratado começou pela higienização, daí foi chamado a trabalhar com hamsters depois que seu modo de manusear os animais - brincalhão e carinhoso - foi observado por Silvana, quando cobria a ausência de um funcionário. Ele diz que Silvana é, como ele, alguém que ama bichos e foi isso que ela reconheceu nele ao contratá-lo.

Mas o amor do qual fala Deraldo não é um sentimento abstrato e geral, é um amor por aquelas criaturas com as quais convive, que atraem sua atenção, correspondem ao afeto e se mostram diferentes umas das outras. Ele que iniciou seu trabalho no biotério cuidando de hamsters, diz que se apaixonou por eles e fez várias descobertas sobre suas qualidades.

Hamsters são bastante dóceis e mais inteligentes do que os camundongos. Eles são inteligentes e sentimentais... O hamster é assim: no primeiro sinal de perigo, ele guarda a comida na boca e depois bota embaixo da maravalha, que ele acha assim: "Aqui é fonte de minha sobrevivência". Aí a gente vê que eles são, né, inteligentes. [...] Só é triste também quando você desmama, porque o camundongo não se pronuncia de tristeza, já o hamster, sim. Os ratinhos gritam por causa da mãe. É complicado, né? [A mãe] reage também algumas vezes, outras prefere o silêncio. Confesso que fiquei triste porque tinha uns animais lá que eu já dava um nome, né, pros hamsters. Tinha uns que eu já conhecia. Tinha uma femeazinha bem novinha, ninguém conseguia pegar, era arisca, mordia, e comigo não, eu botava ela dentro da minha mão (Deraldo, técnico da criação).

Quirino, substituto de Deraldo no cuidado com os hamsters, também foi seduzido por eles e, assim como Deraldo, fez suas descobertas sobre esses animais:

Rapaz, tem hora que ele fica alegre, brincando. Na caixa tem que colocar papel toalha, aí eles pegam, rasgam tudo, faz a casinha deles lá. Acho que nessa hora da construção que eles ficam mais alegres. [...] Eles juntam a maravalha num canto, aí vêm com o papel joga por cima da maravalha, fica tipo uma caverninha. [Quando estão tristes] ficam mais dentro da casinha deles, já observei isso, nem da casa sai, até pra beber água ele só bota a cabecinha pra fora (Deraldo, técnico da criação).

Outros técnicos também se encantam, apreciam, comparam, preferem seus animais por motivos diversos.

Quando a gente esquece a mão assim, talvez devido ao cheiro, aí eles vão pegar na mão, mas nunca morderam, ficam brincando com a luva. [...] É a curiosidade... Os ratos são mais curiosos e brincalhóes que os camundongos (Damasceno, técnico da experimentação).

Ah, uma coisa que eu não esqueço é uns ratos que tinha aqui, que eram nudes. Eles são imunodeficientes e as fêmeas, quando emprenhavam, era muito difícil os filhos nascerem vivos. Então era preciso muito cuidado com os bebês, elas eram muito zelosas, muito carinhosas com os bichinhos. Todo mundo achava eles feios e 
eu gostava deles. Qualquer coisa no olho podia sangrar, aí eu vinha com uma gazezinha, molhava na água, limpava... Aí isso marcou muito minha mente, o cuidado especial com esses animais, o tanto que elas [as mães] são zelosas com os filhos, mais do que os outros (Tatiana, técnica da experimentação).

Os meus animais são só camundongos, pra minha sorte não tem rato, porque aqueles ratos enormes com aqueles rabos... [...] [Camundongos] são bem retadinhos, tem uns que são uns capetinhas, né? Se vacilar eles pulam mesmo, querendo fugir. [...] Imagina, você tá trocando e vendo um bicho pequenininho pulando. Eu fiquei assim besta, vendo o bicho querendo pular, queria porque queria sair. Os bichos só não sabem falar, mas o resto... Eles são espertos (Tânia, técnica da criação).

Rato é uma figura, é muito engraçado. Rato... às vezes fica assim, mó boa vida, deitado de barriga pra cima, só comendo... Rato é muito amigo, mais vale um rato amigo do que um amigo rato [risos] (Silvana, coordenadora da experimentação).

Falar de amor, de preferência ou admiração por animais não equivale a dizer que humanos simplesmente projetam sua subjetividade sobre um alvo inerte. Eles fascinam, mostram qualidades, modos de agir que apelam a certos humanos e isso se faz na convivência e na atenção dedicada aos parceiros no trabalho. Aliás, observar os bichos, como disse, é uma das principais tarefas do cuidador. $E$ isso não envolve apenas olhá-los e tocá-los. A audição também tem sua importância. Várias pessoas mencionaram a existência de brigas entre os camundongos notadas pelo som:

Eles brigam bastante [...]. Eles batem mesmo, tá-tá-tá-tá-tá-tá... na caixa, né? (Tatiana, técnica da experimentação).

Eles fecham o cacete na caixinha, parece que vai estourar a caixa, tum-pá-pá-pá-pá... e eu fico preocupado porque quando começam a morder o rabo do outro, Xavier manda descartar. É uma tristeza, né? (Deraldo, técnico da criação).

Observar os animais faz parte da função do técnico, mas às vezes se instala neles uma disposição para contemplar os bichos que excede aquilo que é demandado pelo trabalho. Alguns deles falam de momentos em que ficam absortos no espetáculo oferecido pela vida e pelo comportamento dos bichos:

Fora que eles brigam bastante, viu? [O casal de camundongos] briga, aí você também vê na hora dos amores e na hora das brigas, né? Aí eu fico assim olhando, eles se cheirando, se beijando. É muito interessante. Tem horas que eu fico assim só observando (Tânia, técnica da criação). Agora, o modo de eles se alimentarem, no dia a dia, a gente acaba se apaixonando pelo jeito deles, o cuidado de pegar a ração com as mãozinhas, de comer... Às vezes você fica horas olhando eles se alimentarem... Aí, às vezes, a gente fica vendo o cuidado que eles têm com os filhotes. São impressionantes... (Damásio, técnico da criação).

Eu acho eles bem carinhosos um com outro. Às vezes eu paro e fico lá, assim, horas olhando o tratamento deles. [...] É, eu observo, eles ficam catando assim, aquele negócio bonitinho, carinhoso, aí eu acho interessante (Bartira, técnica da criação).

Nos casos de brigas mencionados, quando há conflitos mais violentos a consequência é o descarte do "brigão". Justamente a morte do animal é um dos aspectos do trabalho que causa mais inquietude. Muitos sofrem com a exigência de praticar eutanásia - termo preferido pelos locais - nos seus camundongos. $\mathrm{Na}$ maior parte das vezes essa tarefa cabe aos próprios pesquisadores. Mas, às vezes, são os que técnicos precisam realizá-la, em geral por causa das brigas violentas ou quando é preciso descartar casais que não se reproduzem mais com celeridade ou ainda quando eles são requisitados para um experimento, mas acabam não participando dele. Deraldo, por exemplo, lamenta a morte das matrizes porque os bichos poderiam viver mais, 
afinal, nada há de errado com eles - apenas envelheceram. Aí temos certa tensão entre o trabalho do cuidador, que zela pelo bem-estar dos roedores e a lógica da instituição, segundo a qual não há por que manter um animal se ele já não tem função. $\mathrm{O}$ modo instrumental de considerar a criatura viva acaba prevalecendo.

O descarte é uma prática que encontra resistência íntima de vários técnicos. Silvana, por exemplo, trabalhou no canil da instituição e durante dois anos acompanhou cães que faziam parte de uma pesquisa de vacina para leishmaniose. Ela nomeou os cachorros, organizou a vida deles, fez amizade, mas o final do experimento era eutanásia. Ela tirou férias na época e depois deixou o canil pelo biotério.

Também Lena e Damasceno têm dificuldade com o sacrifício:

O que me incomoda mais é ter que sacrificar. Se tiver que fazer, eu faço, mas se eu puder passar pra outra pessoa fazer, eu passo (Lena, técnica do controle de qualidade).

Ratos são dóceis demais. [...] E aí o que aconteceu, rapaz, um dia o chefe chegou pra mim e disse: "Seu Dinho, eu falei com o pesquisador daqueles ratos e ele mandou descartar". Imagine a situação, eu me apeguei aos bichinhos. Rapaz, o que é que eu faço? [...] Aí chegou o grande dia e eu tinha que dar um jeito. [...] Eu não tinha coragem. Aí eu conversei com um ex-funcionário do biotério, ele levou pra mim, colocou na câmara de gás... (Deraldo, técnico do biotério).

Quirino também considera um dos aspectos mais difíceis de seu trabalho a tarefa de fazer eutanásia nos animais. Por se incomodar com o sofrimento, ele aprendeu a controlar o tempo da câmara de gás, para que a morte do animal seja mais suave. Náo é possível conseguir se livrar dessa tarefa desconfortável, mas há caminhos para, ao menos eventualmente, se desviar do mal-estar. Silvana tirou férias, mas, mesmo assim, disse que teve de trabalhar muito, psicologicamente, para enfrentar a situação. Lena e Deraldo, quando podem, passam a tarefa a outros. Damasceno sugere o envio dos bichos para doaçấo ao Ibama quando possível. Para ele, há mais sentido na morte dos camundongos e ratos servindo à vida de outras criaturas vivas:

Pra mim, no caso, o mais difícil pra mim é na hora que tem que fazer a eutanásia. Principalmente dos ratos que a gente tá no dia a dia mexendo, aí às vezes o pesquisador liga: "Ah, a gente náo vai usar mais, pode sacrificar". E a gente tá mexendo com eles todo dia e ter que sacrificar... Tem animal que chega a ano. [...] Hoje mesmo chegaram quatro caixas com filhotinhos, vão ficar até virarem adultos, vou acompanhar o crescimento deles. Aí depois ter que sacrificar eles... E coisa é quando às vezes não chegam a usar. [...] Aí eu digo: "Pô, Silvana, vai sacrificar os bichinhos?” Aí ela, pra não sacrificar, doou pro Ibama. É menos mau, né?

Tanto Damasceno quanto Deraldo fazem referência à necessidade de se desfazer de bichos que foram requisitados para pesquisa, mas acabaram não participando do experimento. A instituição determina que roedores só devem ser mantidos para fins do experimento, portanto, se náo há experimento, é preciso descartá-los. Para Zacarias, o desperdício de animais é um dos aspectos do trabalho que lhe causa mais desconforto. Afinal, o que justifica a sua manutenção no biotério são os benefícios que podem advir da pesquisa. O que dizer quando animais são descartados sem terem atuado em qualquer experimento? E por que pode ser mais razoável, segundo Damasceno, doá-los ao Ibama para alimentar cobras, mesmo sabendo que isso resultará em sofrimento para o camundongo ou rato? Para o pessoal do biotério, a manutençáo do animal nas condiçôes em que vivem e sua morte são justificáveis porque há um fim à vista: a produção de um saber que pode aliviar as dores e enfermidades (inclusive de criaturas não humanas, lembremos que a leishmaniose, por exemplo, também aflige cáes). Alguns argumentam mesmo que a pesquisa que se faz ali está basicamente voltada para atender à população desfavorecida, cujas doenças náo săo de interesse da indústria farmacêutica. Se um animal é descartado, sem ter cumprido o trabalho para o qual foi designado, não realizou seu destino. Quando ele é enviado para o Ibama é como se uma missão substituta lhe 
fosse atribuída, afinal, as cobras resgatadas e mantidas na instituição precisam se alimentar de bichos vivos. Durante uma reunião com técnicos, uma conversa sobre esse tema surgiu e alguém sugeriu que, como os animais eram saudáveis e precisavam ser descartados, talvez fosse possível matá-los sem dor e só depois mandá-los ao Ibama. Outra pessoa jogou por terra a sugestão, dizendo que as cobras caçam e só comem os camundongos se eles estiverem vivos. Mas a busca de outra serventia talvez só ganhe importância porque a lógica da instituição determina o descarte de animais que não são (mais) úteis. Se eles pudessem viver suas vidas até o término sem intervenção humana, a falta de trabalho talvez não importunasse tanto. É o que reivindica Deraldo, por exemplo, ao criticar a morte precoce das matrizes.

É importante ressaltar que muitos dos que exercem atividade no biotério têm uma predileção pela companhia dos animais em relação à dos humanos com os quais convivem ou conviveram em outras situaçôes de trabalho, pois, segundo dizem, eles não competem, não fofocam, não enganam. Consideram que o momento de contato com os animais é o que há de mais agradável no trabalho.

"Eu gosto do meu trabalho porque eu acho mais fácil lidar com os animais do que com gente. Eu tenho certeza que eu não teria dom pra trabalhar em comércio, essas coisas. [...] Esse é um trabalho tranquilo, exige responsabilidade. Eu lido bem com gente, graças a Deus, mas prefiro os animais" (Tatiana, técnica da experimentação). A fruição da convivência com os animais no trabalho se estende para casa, Tatiana, teve um hamster de estimação, Deraldo tem um camundongo macho - Boris - e Lena, um camundongo fêmea - Teodora. Mesmo Zacarias, que não aprova tal prática, se afeiçoou a um coelho nascido com uma mutação no pelo (em vez de liso, era frisado) no biotério onde trabalhava e não permitiu que ele fosse descartado; lhe nomeou Poodle e cuidou dele por muito tempo. Isso revela que os bichos "são grandes parceiros existenciais para os humanos" (Galaty, 2014, p. 33), que auferem grande prazer de sua companhia. Mas isso também pode ser dito da relação dessas criaturas para com os humanos? $\mathrm{O}$ interesse é recíproco? De um modo geral, embora não possamos dizer precisamente em qualquer situação o que interessa aos animais, é possível afirmar que eles respondem à oferta de intimidade oferecida pelos humanos (Idem). No caso específico do biotério, embora não se possa apreender de modo direto o que interessa aos animais, se confiarmos no testemunho daqueles que convivem com eles podemos afirmar que correspondem ao afeto, à tranquilidade, ao carinho e à confiança. Sem dúvida, pode haver mal-entendido e projeção por parte dos humanos, mas mesmo na relação entre humanos e humanos estamos livres de equívocos?

Há ainda um aspecto para o qual quero chamar a atenção a partir dos exemplos apresentados. No caso dos animais nomeados, levados para casa, criados como bichos de estimação, vemos claramente um processo de individualização do animal, que é apartado do coletivo, para ganhar uma vida diferente em outro espaço. No caso dos animais do trabalho é possível observar, ainda que raramente, alguma diferenciação do animal por ser portador de um traço peculiar, a despeito da ênfase na padronização que homogeneíza os que pertencem a uma mesma espécie ou linhagem. Deraldo mencionou a pequena hamster que, sendo muito arisca, era dócil com ele. $\mathrm{O}$ coelho mutante também se distinguiu dos demais. Um rato se tornou conhecido no biotério por ter desenvolvido uma forte aversão por um funcionário.

Esse caso, mencionado por alguns interlocutores da pesquisa, representa um dos poucos exemplos notáveis de individualização do animal no biotério. $\mathrm{Na}$ maior parte das vezes, eles são tratados como parte de uma linhagem, uma espécie, enfim, de uma coletividade. Isso não significa, entretanto, que as diferenças sejam completamente apagadas e que as pessoas não observem peculiaridades ou não formem preferências. Já vimos que Deraldo e Quirino declararam amar os hamsters, enquanto outros tratadores de animais não deixam de notar as particularidades de linhagens e espécies e apreciá-las.

Muitos afirmam que, além de se sentirem mais tranquilos trabalhando com os bichos, também aprenderam muito com a convivência com eles ao prestar atenção ao modo como agem e se expressam. Lena sintetizou assim seu aprendizado:

É, eu acho que a oportunidade de trabalhar com os animais nos faz pessoas melhores, porque você começa a pensar também no sentimento 
de quem não pode se expressar com palavras. Então você começa a tentar perceber nos detalhes o que ele quer passar pra você, né? Então assim, no dia a dia, a gente lida com o animal, aí você olha, ele tá ali no cantinho, por quê? $\mathrm{O}$ que é que tá acontecendo, será que é frio? [...] $\mathrm{E}$ aí você vai procurar, né, maneiras, pra saciar ali aquele animal. Então acho que essa visão, de você se preocupar, de você ficar mais atento aos detalhes, isso é um ganho.

O zelo, a relação empática, é algo que compóe a ética no trato com os animais, para além de outros procedimentos adotados no biotério voltados para seu bem-estar, como o controle da temperatura, da luminosidade, a inclusão do enriquecimento ambiental. A afinidade e atenção são tentativas de contrabalançar a objetificação do animal.

\section{Conclusão}

Neste artigo falei de relaçóes de afeto entre humanos e animais que atuam em um biotério. Mas, ao contrário de estudos de ciência que também apontam para o mesmo fenômeno, não estou tratando de etologistas e dos indivíduos pertencentes às espécies que são seus objetos de interesse. Há relatos sobre etologia acerca do modo como os bichos se tornam mais interessantes quando o cientista dá a eles a chance de se mostrarem mais capazes, mais inteligentes, mais sensíveis a partir do estabelecimento de relaçóes de intersubjetividade (Despret, 2008). Eu tratei aqui de técnicos que atuam em um biotério e de seus animais experimentais.

Poderia parecer, à primeira vista, que nesse âmbito não cabe qualquer esforço para tornar os camundongos, ratos e hamsters mais interessantes, mas o inverso talvez fosse mais verdadeiro. $\mathrm{O}$ trabalho diligente realizado aí está voltado para tornar os animais mais padronizados e purificados. No entanto, isso não significa que no biotério os protocolos sejam estreitos a ponto de impedir qualquer resposta por parte dos bichos, restando a eles agir de maneira meramente mecânica. Aliás, nem mesmo quando um deles corresponde às demandas de trabalho deixa de atuar como uma criatura viva e responsiva. Contudo, não é apenas isso que o animal faz - ele morde, briga, constrói abrigos, tenta fugir - e quem está lá, com os olhos atentos às diferenças, às suas reaçôes, são os técnicos que se deixam afetar por suas respostas, pois aprenderam a ser sensíveis às suas indicaçóes. Todo animal possui potencial para se tornar uma parte imprevisível do dispositivo laboratorial, como argumenta Hansen (2014), embora o modo de organização do biotério contribua para restringir sua capacidade de ação.

Assim, podemos dizer que o trabalho realizado pelo modelo experimental, para o qual ele não foi consultado, pode ser qualificado com trabalho escravo? Se seguirmos o argumento apresentado por Ingold (2000), sim. Ao comparar a relação entre humanos e animais na caça e no pastoreio/domesticação (é possível incluir o biotério nessa categoria), Ingold afirma que na caça os animais vivem em seu mundo e são tratados com respeito e reciprocidade pelos humanos. A confiança seria um elemento essencial dessa relação. Enquanto, para ele, na domesticação há uma perda de capacidade de resposta, pois é o pastor quem provê as condições de vida dos animais e decide sobre sua morte. Além disso, eles são convertidos em propriedade, coisas que podem ser possuídas e comercializadas. Para o autor, o regime de pastoreio se funda em uma relação de dominação e escravização.

Knight (2005) põe em dúvida a concepção de Ingold de que na caçada o caçador efetivamente mantém com sua presa relaçóes semelhantes àquelas que ele estabelece com pessoas, na medida em que o caçador jamais convive por um tempo prolongado com a caça, o que impede a existência de familiaridade e confiança. Mas o que nos interessa aqui é o que se dá na domesticação. Knight sugere que sejamos mais prudentes ao negar a existência de relaçóes responsivas em contextos de domesticação. Para ele, a convivência mais constante e durável pode favorecer ou levar ao surgimento de relaçóes de intimidade e ao reconhecimento de responsividade da parte do bicho. Mas é preciso, para que possamos discernir os traços de pessoalidade em relaçóes de subordinação, não confundir o resultado (animais instrumentalizados, explorados como fonte de alimento e trabalho) com o processo. A preocupação com os resultados talvez esconda uma relação de cuidado na qual a 
criatura viva não pode ser reduzida a objeto (Souza, 2013). Ou seja, não podemos deixar de ver o que acontece na associação cotidiana entre humano e animal, por conta de seu resultado. ${ }^{3}$

Foi por conta da convivência continuada que os técnicos com os quais conversei permitiram que os ratos, camundongos e hamsters se mostrassem espertos, inteligentes, dóceis, briguentos, estressados, curiosos, carinhosos, zelosos com os filhotes, "boas-vidas", como entes vivos e responsivos. Eles mesmos se revelaram sensíveis, cuidadosos, também responsivos e curiosos acerca de seus animais e reconheceram a existência de um senso de mutualidade, quando observavam que animais são capazes de perceber suas disposiçóes e se sintonizar com elas ou quando se deixam tomar pelo silêncio e pela calma exigidos pelos protocolos locais.

A via para que isso pudesse acontecer foram seus corpos, que se tocam, se veem, se ouvem, se cheiram. Através do contato prolongado e sensorial com os animais, os técnicos foram capazes de encontrar distinçóes entre eles, sejam diferenças que individualizam ou marcas de variaçóes coletivas. É claro que não há apenas esse tipo de prática no biotério, e o cuidado não se resume a relaçôes de afeto e empatia física com os animais. Há uma série de rotinas e ordenamentos bem mais objetivos. É crucial para o tratador conseguir equilibrar os dois repertórios de práticas e manejar as tensôes entre eles.

Candea (2010), ao tratar da relação entre pesquisadores e suricatos, argumenta que tanto engajamento quanto neutralidade são componentes necessários da relação com os animais. No contexto do biotério não é diferente. Por vezes, entretanto, a tentativa de combinar as duas atitudes produz tensão. Muitos relatam padecer ao realizar a eutanásia, principalmente se ela é feita com um camundongo ou rato saudável que poderia viver mais. $\mathrm{O}$ senso de dano é menor quando os bichos que são mortos participam da experimentação. Essa atitude parece próxima àquela dos fazendeiros estudados por Law e Mol (2008), que se sentiam vinculados afetivamente a seus rebanhos, objetos de seus cuidados e de uma convivência prolongada. $\mathrm{O}$ afeto não impedia que no momento apropriado as ovelhas fossem enviadas ao abate sem qualquer demonstração de sentimentalismo, mas quando a morte chegava para elas fora do tempo certo, os fazendeiros eram tomados por um sentimento de que haviam falhado em sua missão. ${ }^{4}$

Talvez essas histórias nos deem pistas para repensar a questão da ética na relação entre humanos e animais. Em ambos os casos se trata de reconhecer a emergência de um vínculo e de afetos que surgem quando certas criaturas vivas e sensíveis passam muito tempo juntas, em uma convivência mediada pelo corpo (Greenhough e Roe, 2011). Isso envolve uma sensibilidade ao contexto e uma atenção ao caráter responsivo dos bichos. Talvez justamente aí se apresente um caminho para a construção de uma ética na experimentação que vá além do formal. Esta será uma ética que, como querem Stengers (2005) e Haraway (2008), não apela a um princípio universal que justifique tudo e dê o direito a agir em qualquer situação (seja para permitir ou proibir certas práticas envolvendo os animais). Esse tipo de ética pautada em uma razão superior, geral e inespecífica, ao fim e ao cabo, desresponsabiliza os agentes, porque os exime de prestar atenção às situaçôes e suas singularidades e de agir com discernimento (Stengers, 2005). Para Stengers, ao contrário, é preciso prestar atenção e considerar que as ações fazem parte de um meio de prática e que seus resultados importam.

O pragmatismo e sua concepção de ética podem nos ajudar a pensar esses temas. Segundo Albercht (2004), pensadores como James e Dewey consideram as disposiçóes emotivas para com outros seres um aspecto fundamental de nossa existência e, por isso, elas são pontos de partida legítimos para a insatisfação moral, pois nos dispóem a perceber realidades que não veríamos sem elas. As disposiçóes emotivas podem, portanto, desencadear um processo de hesitação ética (Idem). Nesse caso, a extensão de consideração moral aos bichos, por conseguinte, não depende exclusivamente de argumentos racionais como querem Singer ou Regan (Welchman, 2004). Embora a noçáo de direitos dos animais, para esses autores, se fundamente na noção de senciência, o modo como eles desenvolvem o raciocínio trata essa constatação como uma premissa da qual se depreende um princípio geral: como os animais são sencientes, logo são dotados de direitos. Com isso, o apelo para se pensar sempre em situação, como sugerem Stengers e os pragmatistas, se perde. Mas minha intenção aqui não é opor ra- 
zão e sensibilidade, e sim mostrar como uma ética que incorpora os afetos pode ser mais aberta àquilo que há de perturbador nas situações, tornando-as mais capazes de produzir hesitação. Até porque argumentos racionais são também mobilizados para a defesa de uso de modelos experimentais, e muitos dos técnicos que atuam no biotério aceitam essa justificativa, o que não impede o surgimento do mal-estar com relação à morte dos bichos. É o vínculo afetivo que faz emergir a inquietação ética.

É a proximidade com os animais que fez com que eles valorizassem aquelas vidas, reconhecessem nelas singularidades e interesses. Para James, justamente a luta contra a incapacidade de perceber e valorizar as experiências de outros seres é uma necessidade moral. Ao mesmo tempo, James e Dewey afirmam que a hesitação e a incerteza quanto ao que fazer são próprias da situação ética. $\mathrm{O}$ que traz a marca distintiva de uma ação ética, nesse caso, não é a existência de um princípio moral inflexível, mas a realização de uma escolha. Todo ato ético envolve uma encenação na consciência de futuros possíveis, e a efetivação de um bem pode se dar à custa de outros bens possíveis. Por isso a situaçáo de escolha é trágica (Albrecht, 2004).

Diante de situações de escolhas trágicas, Stengers (2005) nos convoca a não limitarmos nossa imaginação quando precisamos agir na incerteza, sem um princípio geral que justifique tudo. Em muitos casos é melhor não permitir que bichos sejam usados em pesquisa e abrir a imaginação para métodos alternativos, mas, outras vezes, consentir que eles participem de pesquisas pode ser uma dessas escolhas trágicas. Aí também podemos imaginar meios de ampliar a satisfação dos interesses dos animais. Por exemplo, por que não valorizar mais os elementos lúdicos, já que eles mostram grande apreço com a introdução desses componentes? Por que não permitir que vivam por mais tempo, mesmo quando já não têm serventia, mas ainda gozam de saúde e vitalidade? Como fazer para minimizar os casos de animais recrutados, mas não usados nas pesquisas? Que outros destinos poderiam ser dados a eles? E quanto aos trabalhadores humanos, o que poderia ser feito para minimizar os seus sofrimentos?

Ainda que mais questóes como essas possam ser levantadas e respostas possam surgir, que exis- tam os protocolos éticos estabelecidos pelos Ceuas, que mais medidas para tornar as vidas dos animais mais ricas e interessantes sejam tomadas, como diz Haraway (2011), nada disso deve nos dar pleno conforto diante da morte dos bichos. É preciso sustentar o senso de que se trata de uma escolha trágica, que deve sempre ser lamentada e para isso é preciso saber quanto sofrimento ela envolve. É preciso que vejamos com olhos bem abertos o que se passa nos laboratórios e biotérios. Foi isso que tentei fazer neste artigo.

\section{Notas}

1 O material empírico analisado aqui foi obtido no âmbito da pesquisa "Vidas experimentais: conhecendo o inexplorado mundo do biotério e seus habitantes".

2 Para preservar a identidade dos interlocutores desta pesquisa, todos os nomes aqui citados são fictícios.

3 Ainda que seja possível afirmar que o trabalho dos animais é escravo, é preciso fazer algumas observaçôes. A existência de trabalho forçado não diminui a agência do trabalhador, mas antes a afirma. Não há oposição entre trabalho escravo e livre, como se todo trabalho livre fosse necessariamente superior e não abjeto (Haraway, 2008). Por fim, a literatura sobre escravidão mostra que pode haver afeto na relação entre senhor e escravo. Isso de modo nenhum absolve a escravidáo de seus crimes, mas mostra como ela não é capaz de anular completamente a capacidade de ação e resposta dos escravos (Slenes, 1997).

4 Isso não quer dizer que o afeto e o cuidado estejam a serviço da morte, embora a morte aconteça. Eles estão a serviço de um trabalho, do qual a morte é resultado.

\section{BIBLIOGRAFIA}

ALBRECHT, J. (2004), “What does Rome know of rat and lizard?': pragmatic mandates for considering animals. Emerson, James, and Dewey", in E. McKenna e A. Light (orgs.), Animal pragmatism: rethinking human-nonhuman relationships, Bloomington (IN), Indiana University Press.

ASDAL, K. (2008), "Subjected to parliament: the laboratory of experimental medicine and the 
animal body". Social Studies of Science, 38 (6), 899-917.

BIRKE, L. (2012), "Animal bodies in the production of scientific knowledge: modelling medicine”. Body \& Society, 18 (3-4): 156-178.

CANDEA, M. (2010), "II fell in love with Carlos the meerkat': love engagement and detachment in human-animal relations". American Ethnologist, 37 (2): 241-258.

CARVALHO, M. C. (2015), Do Ultrassom e seus corpos: tra(ns)duçóes e práticas de conhecimento em um laboratório universitário. Tese de doutorado, Rio de Janeiro, UFRJ.

CONNOLLY, W. (2005), Pluralism. Durham (NC), Duke University Press.

DAVIES, G. (2010). "Captivating behaviour: mouse models, experimental genetics and reductionist returns in the neurosciences". The Sociological Review, 58 (S1): 53-72.

DESPRET, V. (2004), "The Body we care for: figures of anthropo-zoo-genesis". Body \& Society, 10 (2-3): 111-134.

(2008), "The becomings of subjectivity in animal worlds". Subjectivity, 23: 123-139.

. (2013), "From secret agents to interagency". History and Theory, 52: 29-44.

GREENHOUGH, B. \& ROE, E. (2011), "Ethics, space, and somatic sensibilities: comparing relationships between scientific researchers and their human and animal experimental subjects". Environment and Planning D: Society and Space, 29: 47-66.

HANSEN, P. (2014), "Hokkaido's frontiers: blurred embodiments, shared affects and the evolution of dairy farming's animal-human-machine". Critique of Anthropology, 34 (1): 48-72.

HARAWAY, D. (2008), When species meet. Minneapolis, University of Minnesota Press.

. (2011), "A partilha do sofrimento". Horizontes antropológicos, 35: 27-64.

HOLMBERG, T. (2011), "Mortal love: care practices in animal experimentation". Feminist Theory, 12 (2): 147-163.

INGOLD, T. (2000), "From trust to domination: an alternative history of human-animal relations", in The perception of the envi- ronment: essays in livelihood, dwelling and skill. Nova York, Routledge.

LAW, J. \& MOL, A. (2008), “The actor enacted: Cumbria sheep in 2001", in C. Knappet e L. Malafouris (orgs.), Material agency: towards a non-anthropocentric approach, Boston, Springer.

LYNCH, M. (1988), "Sacrifice and the transformation of the animal into a scientific object: laboratory culture and ritual practices in the neuroscience". Social Studies of Science, 18: 265-289.

SÁ, G. (2010), “'Abraços de mono’: elos perdidos e encontros intersubjetivos em etnografia com primatólogos no Brasil", Mana, 16 (1): 179-211.

SÁ, G.; MEDEIROS, M. F. \& SCHIRMANN, J. S. (2011), "Experiência e descarte: dores humanas e náo humanas em um laboratório de neurotoxidade e psicofarmacologia", Sociedade e Cultura, 14 (2): 427-434.

SLENES, R. (1997), "Senhores e subalternos no oeste paulista”, in F. Novais (coord.) e L. F. Alencastro (org.), História da vida privada no Brasil, vol. 2: Império: a corte e a modernidade nacional, São Paulo, Companhia das Letras.

SOUZA, I. M. A. (2013), "Vidas experimentais: humanos e roedores no laboratório". Etnográfica, 17 (2): 241-268.

STENGERS, I. (2005), "Introductory notes on an ecology of practice". Cultural Studies Review, 11 (1): 183-196.

WELCHMAN, J. (2004), "Is pragmatism chauvinistic? Dewey on animal experimentation", in E. McKenna e A. Light (orgs.), Animal pragmatism: rethinking human-nonhuman relationships, Bloomington, Indiana University Press. 


\section{AFETO ENTRE HUMANOS E ANIMAIS NÃO HUMANOS NO BIOTÉRIO}

\author{
lara Maria de Almeida Souza
}

Palavras-chave: Relação humanos e animais não humanos; Modelo animal; ética; Prática científica; Afetos.

O tema deste artigo são as relaçôes de afeto entre humanos e animais nâo humanos em um contexto de prática científica: um biotério de uma instituição pública que abriga camundongos, hamsters e ratos para pesquisa. Os personagens centrais nesta narrativa são os animais e os técnicos do biotério. Estes últimos, quando relatam suas experiências com os roedores, afirmam que para cuidar bem dos animais não basta seguir os protocolos estabelecidos, sendo preciso também ter um modo afetivo de percebê-los e tocá-los. A existência de um interesse pelo bem-estar do animal para além do protocolar nos permite observar como se constituem trocas intersubjetivas em um campo em que supostamente reinam apenas relações instrumentais. A intenção não é apenas mostrar que afetos permeiam as relaçôes entre não humanos $\mathrm{e}$ humanos, mas explorar como eles podem nos dar indicaçôes por pensar questóes relativas à ética.

\section{AFFECT BETWEEN HUMANS AND NON-HUMAN ANIMALS IN ANIMAL HOUSE}

\section{lara Maria de Almeida Souza}

Keywords: Humans and non-human animals relations; Animal models; Affect; scientific practice; Ethics.

The subject of this article is the relationship of affect between humans and nonhuman animals in a context of scientific practice: an animal house in a public research institution, which shelter mice, rats and hamsters for use in biomedical investigation. The main figures in this narrative are the animals and the technicians working in the animal house. Relating their experiences as caretakers with rodents, these latters say that caring well of animals is more than follow the protocols established on how to treat them, it's necessary an affective way of perceive and touch them. The interest in well being of animal beyond the protocol and instrumental action, allow us to have a glimpse on the existence of intersubjective relations in a field where supposedly only have place objective and instrumental relations. My intention however is not so point to affects that pervade relationships between human and non human animals, but also explore the consequences to rethink animal ethics.

\section{AFFECTION ENTRE HUMAINS ET ANIMAUX NON HUMAINS DANS UN VIVARIUM}

\author{
lara Maria de Almeida Souza
}

Mots-clés: Relation humaine et animal; Modèle animal; L'éthique; La pratique scientifique; Affections.

Cet article porte sur les relations d'affection entre les animaux humains et non humains dans un contexte de pratique scientifique, et plus précisément dans le vivarium d'une institution publique qui abrite des souris, des hamsters et des rats destinés à la recherche. Les personnages centraux de ce récit sont les animaux et le personnel du vivarium. Ces techniciens affirment à propos de leurs expériences auprès des rongeurs, que pour garantir la qualité des soins, il ne suffit pas de suivre les protocoles déterminant assez strictement les façons de traiter ces animaux. Il est également nécessaire de les percevoir d'une forme affective et surtout de les toucher. L'existence d'un intérêt envers le bien-être de l'animal qui ne soit pas exclusivement protocolaire et instrumental donne à voir la façon dont sont constitués des échanges intersubjectifs dans un domaine où ne sont censés régner que des relations de nature objective / instrumentale. L'intention est ici non seulement de montrer que les émotions imprègnent la relation entre les humains et les animaux non humains, mais aussi d'exploiter ce constat pour repenser certaines questions relatives à l'éthique, audelà des aspects formels proposés au sein des réglementations. 